\title{
Eustrongylides sp. (Nematoda, Dioctophymatoidea) parasitizing Hoplias malabaricus (Actinopterygii: Erythrinidae) collected from the state of Rio de Janeiro, Brazil
}

\author{
Eustrongylides sp. (Nematoda, Dioctophymatoidea) parasitando Hoplias \\ malabaricus (Actinopterygii: Erythrinidae) coletados do Estado do Rio de \\ Janeiro, Brasil
}

\author{
Bianca Porto Kuraiem ${ }^{1}$, Marcelo Knoff ${ }^{\star *}$ (D), Erich Loza Telleria ${ }^{3}$, \\ Michelle Cristie Gonçalves da Fonseca², Leandro dos Santos Machado4, \\ Nathalie Costa da Cunha ${ }^{4}$, Elmiro Rosendo do Nascimento ${ }^{4}$, Gabrielle Fontenelle ${ }^{1}$, \\ Delir Corrêa Gomes², Sérgio Carmona de São Clemente ${ }^{1}$
1 Laboratório de Inspeção e Tecnologia do Pescado, Faculdade de Medicina Veterinária, Universidade Federal Fluminense - UFF, Niterói, RJ, Brasil
${ }^{2}$ Laboratório de Helmintos Parasitos de Vertebrados, Instituto Oswaldo Cruz, Fundação Oswaldo Cruz - FIOCRUZ, Rio de Janeiro, RJ, Brasil
${ }^{3}$ Department of Parasitology, Faculty of Science, Charles University, Prague, Czech Republic
${ }^{4}$ Laboratório de Epidemiologia Molecular, Faculdade de Medicina Veterinária, Universidade Federal Fluminense - UFF, Niterói, RJ, Brasil

How to cite: Kuraiem BP, Knoff M, Telleria EL, Fonseca MCG, Machado LS, Cunha NC, Nascimento ER, Fontenelle G, Gomes DC, São Clemente SC. Eustrongylides sp. (Nematoda, Dioctophymatoidea) parasitizing Hoplias malabaricus (Actinopterygii: Erythrinidae) collected from the state of Rio de Janeiro, Brazil. Braz J Vet Parasitol 2020; 29(1): e014519. https://doi.org/10.1590/S1984-29612019094

\begin{abstract}
Hoplias malabaricus (Characiformes, Erythrinidae), trahira, is a neotropical freshwater fish of economic and public health significance. A total of 45 specimens of $H$. malabaricus commercialized in the municipality of Magé, state of Rio de Janeiro, Brazil, were acquired between April 2016 and April 2018 to investigate the presence of nematode larvae. Twenty of the fish were found parasitized by 347 fourth-stage nematode larvae identified taxonomically as Eustrongylides sp. using morphological, morphometric and molecular data. The parasitic indices were: prevalence $44.44 \%$, mean intensity 17.35, mean abundance 7.71, and range of infection 2-40. Infection sites were musculature, mesentery, abdominal cavity, and serosa of intestine, stomach and liver. This is the first report of Eustrongylides sp. larvae parasitizing H. malabaricus in the state of Rio de Janeiro.
\end{abstract}

Keywords: Eustrongylides sp., Nematode, Hoplias malabaricus, Brazil.

\section{Resumo}

Hoplias malabaricus (Characiformes, Erythrinidae), traíra, é um peixe neotropical de água doce que tem significante impacto na economia e saúde pública. De abril de 2016 a abril de 2018, foram adquiridos 45 espécimes de $H$. malabaricus comercializados no município de Magé, Estado do Rio de Janeiro, Brasil. Os peixes foram necropsiados e filetados para investigação da presença de larvas de nematoides. Vinte dos peixes coletados estavam parasitados por 347 larvas de nematoides, identificadas taxonomicamente como larvas de quarto estágio de Eustrongylides sp. usando-se dados morfológicos, morfométricos e moleculares, apresentando os seguintes valores: prevalência de 
44,44\%, intensidade média de 17,35, abundância média de 7,71, e amplitude de variação da infecção de 2-40. Os sítios de infecção foram musculatura, mesentério, cavidade abdominal e serosas do intestino, estômago e fígado. Este é o primeiro registro de larvas de Eustrongylides sp. parasitando $H$. malabaricus no Estado do Rio de Janeiro.

Palavras-chave: Eustrongylides sp., Nematoide, Hoplias malabaricus, Brasil.

Hoplias malabaricus (Bloch, 1794), trahira, is a nocturnal neotropical fish that occurs in Central and South American freshwater ecosystems (GODOY, 1975; OYAKAWA, 2003). It is an agile and voracious predator that attacks a wide variety of fish species, consequently creating favorable conditions for the maintenance and spread of parasites in the aquatic environment (BARROS et al., 2007; MONTENEGRO et al., 2013). The species is appreciated and well accepted by consumers, and has good fillet yield, lean meat and high nutritional value, mainly in relation to protein, and thus has economic and public health significance (SANTOS et al., 2001). The definitive hosts of nematodes of the genus Eustrongylides are piscivorous birds, while their larvae infect oligochaetes, fish and occasionally amphibians and reptiles (MORAVEC, 1998; COLE, 1999). According to Barros et al. (2004), humans may become accidental hosts after ingesting raw or undercooked infected fish, and may develop gastritis and intestinal perforation, resulting in severe abdominal pain and potential surgical removal of the larvae (KNOFF \& GOMES, 2012; MITCHELL et al., 2009). Human infection by Eustrongylides spp. has been reported in the USA and South Sudan (EBERHARD et al., 1989; EBERHARD \& RUIZ-TIBEN, 2014; GUERIN et al., 1982; GUNBY, 1982; WITTNER et al., 1989; NARR et al., 1996). There are no records of this parasitism of humans in Brazil, although the possibility cannot be ruled out because these nematodes have been recorded in several species of freshwater fish in many states of the country (BARROS et al., 2006; BENIGNO et al., 2012; EIRAS et al., 2010; RODRIGUES et al., 2015; TAVARES et al., 2017). Infection of $H$. malabaricus by larval Eustrongylides sp. has been reported in the Brazilian states of Pará, Maranhão, Rondônia, Mato Grosso and São Paulo (REGO \& EIRAS, 1988; REGO \& VICENTE, 1988; BARROS et al., 2007; MARTINS et al., 2009; BENIGNO et al., 2012; MENEGUETTI et al., 2013; RODRIGUES et al., 2017). This infection has yet to be documented in the state of Rio de Janeiro. The aim of the present study was to assess the presence of nematode larvae parasitizing $H$. malabaricus in the municipality of Magé, state of Rio de Janeiro, Brazil. Encountered nematode species were identified using morphological and morphometric characters, and their parasitic indices calculated and infection sites recorded.

From April 2016 to April 2018, a total of 45 specimens of $H$. malabaricus (total length $13-$ $46 \mathrm{~cm}, 24.84 \mathrm{~cm} \pm 7.52$; weight 25-1,110 g, $220.26 \mathrm{~g} \pm 230.37$ ) were acquired from local artisanal fishermen in the municipality of Magé, state of Rio de Janeiro, Brazil $\left(22^{\circ} 39^{\prime} 10^{\prime \prime} \mathrm{S}\right.$; $43^{\circ} 02^{\prime} 26^{\prime \prime} \mathrm{W}$ ). The fish were transported in isothermal boxes to the laboratory where they were kept in a freezer until necropsy. The fish were identified in accordance with Godoy (1975). Internal organs and musculature were examined and all Eustrongylides specimens found were placed in Petri dishes with $0.65 \% \mathrm{NaCl}$ solution. Specimens were fixed in AFA (ethanol, formalin, and acetic acid); preserved in 70\% ethanol, 5\% glycerinated; and clarified with Aman's Lactophenol, according to Knoff \& Gomes (2012). Taxonomic classification of nematodes followed De Ley \& Blaxter (2002), while morphological identification relied on Measures (1988a, b) and Moravec (1998). Samples were analysed with an Olympus BX 41 bright-field microscope. Measurements are given in micrometers $(\mu \mathrm{m})$ with averages in parentheses, unless otherwise indicated. Some specimens were prepared for scanning electron microscopy (SEM) as described by Lopes Torres et al. (2013). The samples fixed in $70 \%$ ethanol were dehydrated in an ethanol series ( $70 \%$ to $100 \%$ ) followed by $\mathrm{CO}_{2}$ critical point drying. They were then coated in gold, examined and photographed using a JEOLJSM6390 LV scanning electron microscope under $15 \mathrm{kV}$ acceleration voltage in the Plataforma de Microscopia Eletrônica Rudolf Barth (IOC-Fiocruz). The parasitic indices of prevalence, 
mean intensity, mean abundance and range of infection were obtained as described by Bush et al. (1997). Representative specimens of nematodes were deposited in the Helminthological Collection of the Oswaldo Cruz Institute (CHIOC), Rio de Janeiro, Brazil. One specimen of Eustrongylides sp. recovered from a specimen of $H$. malabaricus was analyzed genetically. The specimen was placed in phosphate-buffered saline (PBS) and frozen in a microtube at $-20^{\circ} \mathrm{C}$. The sample was then deposited in liquid nitrogen and crushed with a sterile micropestle prior to DNA extraction using a MasterPure DNA purification kit (Epicentre, Madison, Wisconsin, USA). The DNA was amplified using a conventional polymerase chain reaction (PCR). The primers 18SF (5'TTGGATGATTCGGTGAGGT- $3^{\prime}$ ) and 28SR (5' -AACCGCTTAGTAATATGCT- $3^{\prime}$ ) were used to amplify the internal transcribed spacer (ITS) rDNA region (XIONG et al., 2013). PCR was carried out in a final volume of $50 \mu \mathrm{l}$ containing a mixture of $2 \mu \mathrm{l}$ of DNA isolate, $1.25 \mathrm{U}$ of Taq polymerase (Platinum Taq DNA Polymerase, Thermo Fisher Scientific, Waltham, Massachusetts, USA), $1 \times$ PCR buffer (10 millimolar [mM] of Tris-HCl, $\mathrm{pH} 8.0$; and 50mM of $\mathrm{KCl}$ ), 2- $\mathrm{mM}$ of $\mathrm{MgCl}_{2}, 0.2 \mathrm{mM}$ of deoxynucleoside triphosphate (dNTP) mixture and $0.2 \mathrm{mM}$ of forward and reverse primers. A negative control (ultrapure water) was included in the PCR reaction. The amplification of parasite DNA was performed using a PTC-100® (BioRadLaboratories, Ltd., Hertfordshire, UK) following the cycle of the primers (XIONG et al., 2013). The PCR products were stained using GelRed ${ }^{\mathrm{TM}}$ and were viewed by means of electrophoresis on a 1.5\% agarose gel. Amplicons of expected size were purified by means of the Wizard SV Genomic DNA Purification System (Promega ${ }^{\mathrm{TM}}$ ). Forward and reverse nucleotide sequences were determined using a DNA sequence analyzer (ABI3730xlv; Thermo Fisher Scientific, Waltham, Massachusetts, USA). Partial Eustrongylides sp. internal transcribed spacer (ITS) rDNA gene sequences (RJ isolate) were trimmed for quality and assembled in contigs with CLC Main Workbench software, version 7.6.4 (Qiagen, Aarhus $\mathrm{A} / \mathrm{S}$, Denmark). The resulting consensus sequences were used as query for nucleotide BLAST analysis against the NCBI database in order to determine similarity to species of the nematode genus Eustrongylides (ALTSCHUL et al., 1990). Closely related ITS rDNA gene sequences from other organisms were selected from GenBank (BENSON et al., 2015) and were used in multiple alignments together with sequences from Trichuris skrjabini, $T$. discolor and T. trichiura chosen as outgroups. Regions that could not be unambiguously aligned due to length variation were excluded from the analysis. All sequence analyses and multiple alignments were performed using the CLC Main Workbench software. A phylogram was generated using ITS rDNA sequences in MEGA 6.06 software (TAMURA et al., 2013). Evolutionary history was predicted using the Maximum Likelihood method and the Kimura 2-parameter model (KIMURA, 1980), applying Neighbor-Join and BioNJ algorithms to a matrix of pairwise distances estimated using the Maximum Composite Likelihood (MCL) approach. Bootstrap testing was performed with 4000 replicates.

A total of 347 fourth-stage larvae of Eustrongylides sp. were collected from H. malabaricus; 277 from musculature, three from stomach serosa, 14 from intestinal serosa, 13 from liver serosa, 10 from mesentery and 30 from the abdominal cavity. Most of the larvae were within round capsules entwined in musculature with the exception of some free larvae found in the abdominal cavity. The nematodes were taxonomically identified as follows: Dioctophymatida Baylis \& Daubney, 1926; Dioctophymatina Skrjabin, 1927; Dioctophymatidae Castellani \& Chalmers, 1910; Eustrongylinae Chitwood \& Chitwood, 1937; Eustrongylides Jägerskiöld, 1909; Eustrongylides sp. fourth-stage larvae (Figures 1, 4). The main morphological characters observed in 10 fourth-stage larvae from H. malabaricus: Large nematodes. Long body with thinner ends. Bright red in color. Thin cuticle with transverse striations particularly marked at the ends. Cephalic end conical with 12 labial papillae arranged in two circles (inner and outer) of six papillae each, including two lateral, two subventral and two subdorsal. Inner and outer papillae almost equal in size. Inner papillae with narrow bases and spine-like apices. Outer papillae with wide bases 
and nipple-like apices. Lateral labial papillae of both circles more anterior than subventral and subdorsal labial papillae. Four small flat papillae present between inner and outer circles of labial papillae, with variable position. Small flat ventral papilla present between two outer subventral labial papillae. Somatic papillae present in one row in each lateral field from the anterior to the posterior end, becoming proximate to one another at the ends of the larva. Flat caudal papillae in dorsal and lateral fields, numerous and variable in number and position. Narrow buccal cavity. Mouth variable in shape, usually a dorsoventral slit. Long glandular oesophagus. Nerve ring shortly after oesophagus-buccal cavity junction. Male: developed caudal sucker with a small cuticular edge around the perimeter. The genital primordium of male larvae consists of four regions. A thick-walled genital tube (ejaculatory duct) with circular muscles extends anteriorly from the rectum, generally looping several times. Wide genital tube, consisting of longitudinal and circular muscles (seminal vesicle), ends shortly before the genital tube narrows and its wall thickens. The genital tube extends further anteriorly and the walls became thin a small or imperceptible lumen; the tube lacks muscles (vas efferens). The genital tube then curves posteriorly near the oesophageal-intestinal junction and after a short distance expands into a large, thin-walled, hologonic testis with a blunt terminus. The spicule is incompletely sclerotized. The dorsal wall of the posterior part of the rectum has small, posteriorlydirected spiny projections. Female: the genital primordium of female larvae consists of four regions. A thick-walled vagina consisting of cuboidal epithelium and circular muscles with an inner cuticular layer. Wide genital tube and the lumen narrows (uterus). The genital tube consists of circular muscles and a small or imperceptible lumen extends further anteriorly (oviduct). The genital tube curves posteriorly and expands into a large, thin-walled hologonic ovary with a tapered terminus. The genital tube of male and female larvae is supported by a well-developed process to the body wall. Numerous small papillae, some bifid or trifid distally, are present in small groups on the posterior extremity of male and female fourth-instar larvae. Three cuticles are visible on these fourth-instar larvae the outer and middle cuticles of second and third-stages, respectively, and the inner cuticle of fourthstage. Morphometric data are shown in Table 1. The parasitic indices, as well as the infection sites and the deposit number at $\mathrm{CHIOC}$ are provided in Table 2.

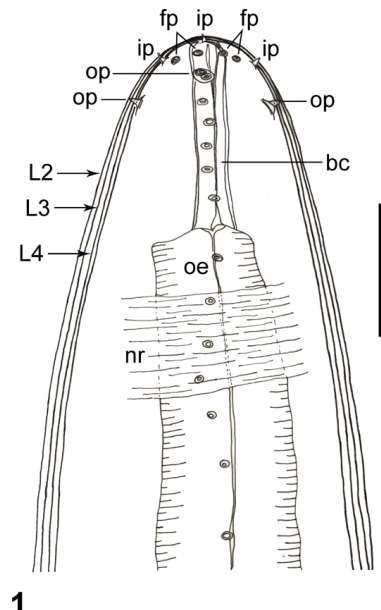

1

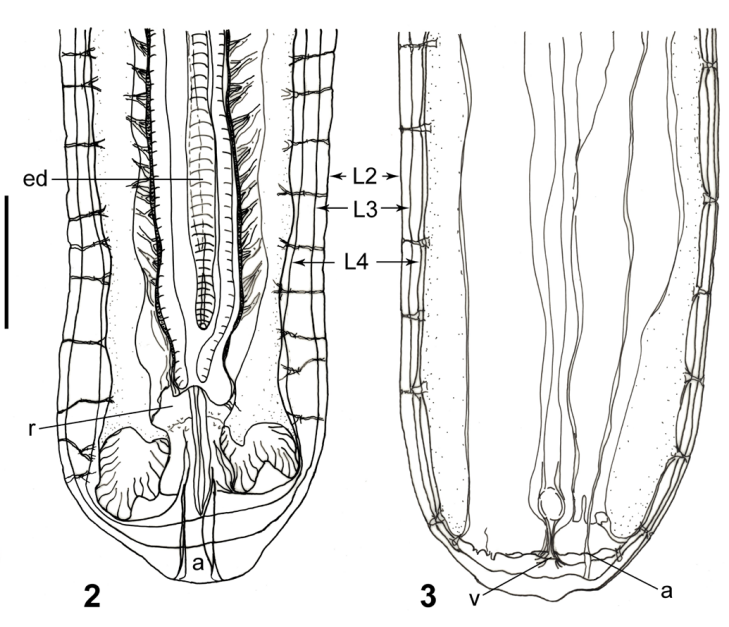

2

Figures 1-3. Fourth-instar larvae of Eustrongylides sp. from $\mathrm{H}$. malabaricus. 1. Cephalic end of female larva, lateral view. Shown are three cuticle layers, L2, L3 and L4, inner papillae (ip), outer papillae (op), flat papillae (fp), buccal cavity (bc), oesophagus (oe) and nerve ring (nr). 2. Caudal end of male larva, ventral view. Shown three cuticle layers, L2, L3 and L4, ejaculatory duct (ed), rectum ( $r$ ) and anus (a). 3. Caudal end of female larva, lateral view. Shown three cuticle layers, L2, L3 and L4, vulva (v) and anus (a). Scale bar $=200 \mu \mathrm{m}$. 

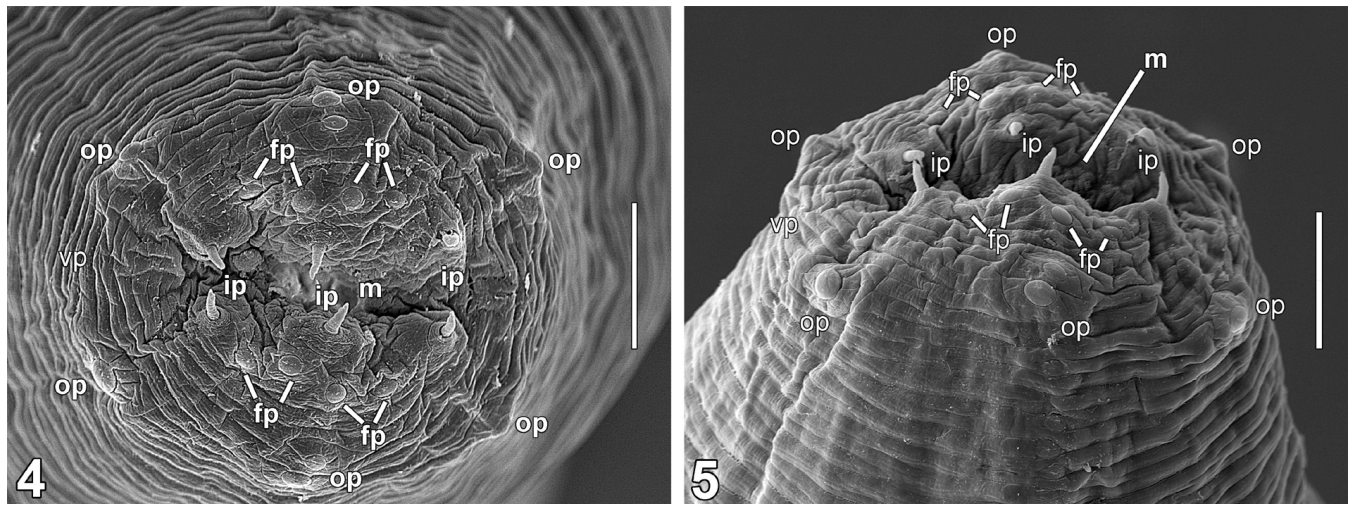

Figures 4-5. Scanning electron micrographs of the cephalic end of a fourth-instar larva of Eustrongylides sp. from H. malabaricus. 4. Apical view. 5. Ventro-lateral view. Shown inner papillae (ip), outer papillae (op), flat papillae (fp), ventral papilla (vp) and mouth (m). Scale bars of 4 and $5=40 \mu \mathrm{m}$.

Table 1. Morphometric data of fourth-stage larvae of the Eustrongylides sp. collected from Hoplias malabaricus (Bloch, 1794) from municipality of Magé, state of Rio de Janeiro, Brazil.

\begin{tabular}{ccc}
\hline & Female $(\mathbf{n}=\mathbf{4})$ & Male $(\mathbf{n}=\mathbf{6})$ \\
\hline Body length $(\mathrm{mm})_{\text {Nerve ring }^{*}}$ & $76.37-153.57(105.22)$ & $57.70-136.90(84.58)$ \\
Width at nerve ring & $240-315(291.25)$ & $250-405(287.50)$ \\
Width at oesophageal-intestinal junction & $300-570(381.25)$ & $270-750(377.50)$ \\
Oesophagus length $(\mathrm{mm})$ & $594.60-975(714)$ & $510-875(611)$ \\
Rectum $^{* *}$ & $16.10-20.15(17.84)$ & $12.15-22.5(16.05)$ \\
Width at posterior end & $250-255(251.60)$ & $220-260(236)$ \\
\hline
\end{tabular}

*Distance from anterior end;

**Distance from posterior end; $n=$ number of measured specimens. Measurements are in micrometres unless indicated otherwise.

Table 2. Parasitic indices of prevalence $(P)$, mean intensity $(\mathrm{MI})$, mean abundance (MA), range of infection (RI), sites of infection (SI) and deposit numbers in the Helminthological Collection of the Oswaldo Cruz Institute (CHIOC) of Eustrongylides sp. fourthstage larvae from Hoplias malabaricus commercialized in the municipality of Magé, state of Rio de Janeiro, Brazil.

\begin{tabular}{ccccccc}
\hline & $\mathbf{P ( \% )}$ & MI & MA & RI & SI & CHIOC \\
\hline Eustrongylides & & & & & 38591,38592, \\
sp. & 44.44 & 17.35 & 7.71 & $2-40$ & M, St, I, L, Me, & 38593,40062, \\
& & & & Ac & 40063,40064, \\
& & & & 40065,40066 \\
\hline
\end{tabular}

$\mathrm{M}$ = musculature; $\mathrm{St}$ = serosa of stomach; I = serosa of intestine; $\mathrm{L}=$ serosa of liver; $\mathrm{Me}=$ mesentery; $\mathrm{Ac}=$ abdominal cavity.

Three additional unpublished specimens of Eustrongylides sp. fourth-stage larvae parasitizing $H$. malabaricus in the state of Rio de Janeiro were found deposited at CHIOC. The first was deposited by Carlos Moreira in July 07, 1917, collected at the locality of Quinta da Boa Vista, municipality of Rio de Janeiro (CHIOC 8500) and identified by Lauro P. Travassos; the other two were deposited by Evaldete Ferraz de Oliveira on April 13, 1983, and December 20,1983, both collected from the locality of Rio da Guarda, municipality of Itaguaí (CHIOC 32263 and 32267) and identified by Evaldete F. Oliveira and José Felipe R. Amato in 1984. These specimens notwithstanding, the present paper is the first published report of $H$. malabaricus being parasitized by Eustrongylides sp. larvae in the state of Rio de Janeiro.

Comparison of the sequence of the one specimen used to amplify partial ITS rDNA sequences (879 nucleotides, GenBank MK650418) with the same gene sequences available 
in the GenBank database revealed that the ITS rDNA sequences are $77 \%$ to $81 \%$ similar to ITS rDNA of other Eustrongylides spp. The phylogram generated (Figure 6) using sequences from Eustrongylides spp. shows that the parasite in the Rio de Janeiro isolate (present work) groups with other Eustrongylides spp. isolates, but in a separate sub-branch.

The nematodes identified as fourth-stage larvae of Eustrongylides sp. in the present study morphologically resemble those previously recorded as fourth-stage larvae of E. tubifex (Nitzsch in Rudolphi, 1819) Jägerskiöld, 1909, collected from Ambloplites rupestris (Rafinesque, 1817) and Lepomis gibbosus (Linnaeus, 1758) from Canada, experimentally infected by Measures (1988b); and fourth-stage larvae of E. ignotus Jägerskiöld, 1909, collected from Monopterus albus (Zuiew, 1793), from Hubei Province, China, by Xiong et al. (2009) and collected from Gambusia affinis (Baird \& Girard, 1853), by Coyner et al. (2002). Although the largest specimens of the present study are larger than the specimens reported by Measures (1988b) (female $=69.5$ [45.1-83.4] and male $=55.1$ [32.2-66.0]) and Xiong et al. (2009) (female $=52.6$ [42-65] and male $=45$ [40$54])$, this may be due to a smaller size range of specimens collected by these authors. This, therefore, reinforces Measures (1988b), Coyner et al. (2002) and Moravec (1998), who reported that the fourth-stage larvae of Eustrongylides spp. could not be identified to the species level by morphological and morphometric characteristics alone, unless there was an experimental infection in a definitive host (aquatic birds) to obtain an adult nematode. The Eustrongylides sp. larvae encountered in the present study were identified as fourth-stage by size, number of cuticles (three) and having a well-developed reproductive system, as observed by Measures (1988b), Coyner et al. (2002) and Xiong et al. (2009). Although they did not measure larval structures, Rego \& Vicente (1988) reported a larvae body length for larvae $(50-133 \mathrm{~mm})$ collected from $\mathrm{H}$. malabaricus from the Cuiabá river, state of Mato Grosso, Brazil, within the range reported here $(76.37-153.57 \mathrm{~mm})$.

In spite of the few ITS gene regions available for nematode species of relevance to fish parasitology, the ITS sequence of the present study was found to be similar to other Eustrongylides spp. isolates reported by Xiong et al. (2013), while sequences of Capilllarinae and Trichuris formed an outergroup (Figure 6). The phylogenetic analysis performed with ITS rDNA multiple alignment supported its taxonomic position within the Eustrongylides spp. group. Identification to species level using molecular data has not yet to be developed, and so the combination of morphological and molecular analyses presented here provide that the nematode belongs to genus Eustrongylides.

The present study showed a prevalence of Eustrongylides sp. on H. malabaricus ( $P=44.44 \%)$ is smaller than related in North Region of Brazil by Benigno et al. (2012) $(P=53.85 \%)$ and by Meneguetti et al. (2013) ( $P=93.3 \%)$. Interestingly, Benigno et al. (2012) and Meneguetti et al. (2013) found, as in the present study, that the majority of larvae (80\%) were in musculature, which represents an increased risk of human infection. This is true even given that larvae of Eustrongylides sp. are large, since they were found winding inside fish musculature, which could hinder visualization. 


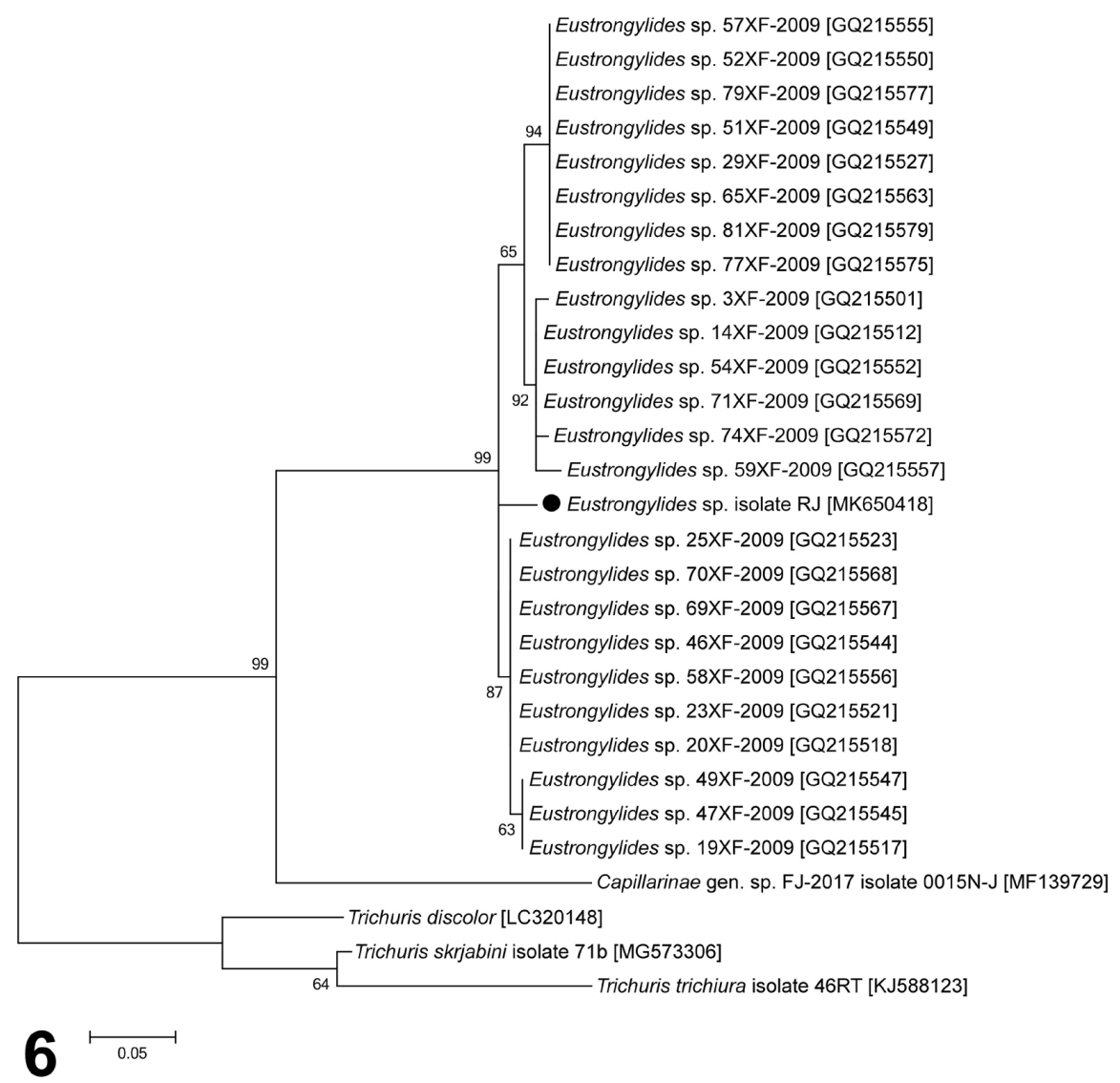

Figure 6. Neighbor-joining phylogram inferred from concatenated partial DNA sequences of Eustrongylides sp. Branches for each DNA sequence with species names are indicated, corresponding GenBank accession numbers; bootstrap values are indicated on nodes. Scale bar represents the expected number of substitutions per nucleotide.

According to Brazilian Regulation of Industrial and Sanitary Inspection of Animal Products - RIISPOA (BRASIL, 1952), fish with massive parasite infestation of muscle are inappropriate for human consumption. Besides the disgusting aspect caused by the large size of the larvae, and the high prevalence found in this study, the consumption of raw or undercooked parasitized fish can lead to human infection by live Eustrongylides sp. larvae. This highlights the importance of educating the population about the risks of eating raw or undercooked fish, and the need to intensify surveillance of fish served to the public. More research is needed to better understand the mechanisms of infection and allergenic potential of Eustrongylides sp. larvae in humans. Research into the immunological responses of BALB/c mice to crude extract of the Eustrongylides sp. larvae found in the present study is currently in progress.

\section{Acknowledgements}

The authors would like to thank Ricardo Baptista Schmidt (Serviço de Produção e Tratamento de Imagens, IOC/Fiocruz) for processing the figures, to the staff of Plataforma de Microscopia Eletrônica Rudolf Barth, IOC/Fiocruz by the images of SEM and to Coordenação de Aperfeiçoamento de Pessoal de Nível Superior (CAPES) for partial financial supports. This work was supported by Conselho Nacional de Desenvolvimento Científico e Tecnológico (CNPq) fellowships (SCSC: 308048/2013-8; MCGF: 150140/2018-5). 


\section{References}

Altschul SF, Gish W, Miller W, Myers EW, Lipman DJ. Basic local alignment search tool. J Mol Biol 1990; 215(3): 403-410. http://dx.doi.org/10.1016/S0022-2836(05)80360-2. PMid:2231712.

Barros LA, Moraes Filho J, Oliveira RL. Nematóides com potencial zoonótico em peixes com importância econômica provenientes do rio Cuiabá. R Bras Ci Vet 2006; 13(1): 55-57. http://dx.doi.org/10.4322/rbcv.2014.267.

Barros LA, Moraes J Fo, Oliveira RL. Larvas de nematóides de importância zoonótica encontradas em traíras (Hoplias malabaricus Bloch, 1794) no município de Santo Antonio do Leverger, MT. Arq Bras Med Vet Zootec 2007; 59(2): 533-535. http://dx.doi.org/10.1590/S0102-09352007000200042.

Barros LA, Tortelly R, Pinto RM, Gomes DC. Effects of experimental infections with larvae of Eustrongylides ignotus Jäegerskiöld, 1909 and Contracaecum multipapillatum (Drasche, 1882) Baylis, 1920 in rabbits. Arq Bras Med Vet Zootec 2004; 56(3): 325-332. http://dx.doi.org/10.1590/S0102-09352004000300007.

Benigno RN, Clemente SC, Matos ER, Pinto RM, Gomes DC, Knoff M. Nematodes in Hoplerytrinus unitaeniatus, Hoplias malabaricus and Pygocentrus nattereri (pisces characiformes) in Marajó Island, Brazil. Rev Bras Parasitol Vet 2012; 21(2): 165-170. http://dx.doi.org/10.1590/S198429612012000200018. PMid:22832760.

Benson DA, Clark K, Karsch-Mizrachi I, Lipman DJ, Ostell J, Sayers EW. GenBank. Nucleic Acids Res 2015; 43(Database issue): D30-35. http://dx.doi.org/10.1093/nar/gku1216. PMid:25414350.

Brasil. Ministério da Agricultura e do Abastecimento. Decreto n 30.691, de 29 de março de 1952. Regulamento de Inspeção Industrial e Sanitária de Produtos de Origem Animal (RIISPOA). Diário Oficial da República Federativa do Brasil, Brasília, jul. 1952.

Bush AO, Lafferty KD, Lotz JM, Shostak AW. Parasitology meets ecology on its own terms: margolis et al. revisited.J Parasitol 1997; 83(4): 575-583. http://dx.doi.org/10.2307/3284227. PMid:9267395.

Cole RA. Eustrongylidosis. In: Friend M, Franson JC, editors. Field manual of wildlife diseases: general field procedures and diseases of birds. Washington: U. S. Geological Survey; 1999. p. 223-228.

Coyner DF, Spalding MG, Forrester DJ. Epizootiology of Eustrongylides ignotus in Florida: Distribution, density, and natural infections in intermediate hosts. J Wildl Dis 2002; 38(3): 483-499. http://dx.doi.org/10.7589/0090-3558-38.3.483. PMid:12238365.

De Ley P, Blaxter M. Systematic position and phylogeny. In: Lee D, editor. The biology of nematodes. London: Taylor \& Francis; 2002. p. 1-30. http://dx.doi.org/10.1201/b12614-2.

Eberhard ML, Hurwitz H, Coletta D, Sun AM. Intestinal perforation caused by larval Eustrongylides (Nematoda: Dioctophymatoidae) in New Jersey. Am J Trop Med Hyg 1989; 40(6): 648-650. http://dx.doi.org/10.4269/ajtmh.1989.40.648. PMid:2742040.

Eberhard ML, Ruiz-Tiben E. Cutaneous emergence of Eustrongylides in two persons from South Sudan. Am J Trop Med Hyg 2014; 90(2): 315-317. http://dx.doi.org/10.4269/ajtmh.13-0638. PMid:24379241.

Eiras JC, Takemoto RM, Pavanelli GC, Adriano EA. Diversidade dos parasitas de peixes de água doce do Brasil. Maringá: Clichetec; 2010.

Godoy MP. Peixes do Brasil: Subordem Characoidei. Piracicaba: Franciscana; 1975.

Guerin PF, Marapudi S, McGrail L, Moravec CL, Schiller E, Hopf EW, et al. Epidemiologic notes and reports intestinal perforation caused by larval Eustrongylides Maryland. MMWR 1982; 31(28): 383-389.

Gunby P. One worm in the minnow equals too many in the gut. JAMA 1982; 248(2): 163. http://dx.doi.org/10.1001/jama.1982.03330020011004. PMid:7087103.

Kimura M. A simple method for estimating evolutionary rates of base substitutions through comparative studies of nucleotide sequences. J Mol Evol 1980; 16(2): 111-120. http://dx.doi.org/10.1007/BF01731581. PMid:7463489.

Knoff M, Gomes DC. Metodologia básica para coleta e processamento de helmintos parasitos. In: Molinaro EM, Caputo LFG, Amendoeira MRR, editors. Conceitos e métodos para a formação de profissionais em laboratórios de saúde. Rio de Janeiro: EPSJV, IOC; 2012. p. 251-281. vol. 5.

Lopes Torres EJ, Souza W, Miranda K. Comparative analysis of Trichuris muris surface using conventional, low vacuum, environmental and field emission scanning electron microscopy. Vet Parasitol 2013; 196(3-4): 409-416. http://dx.doi.org/10.1016/j.vetpar.2013.02.026. PMid:23537947. 
Martins ML, Santos RS, Marengoni NG, Takahashi HK, Onaka EM. Seasonality of Eustrongylides sp. (Nematoda: Dioctophymatidae) larvae in fishes from Paraná River, South-western Brazil. Bol Inst Pesca 2009; 35(1): 29-37.

Measures LN. Revision of the genus Eustrongylides Jägerskiöld, 1909 (Nematoda: Dioctophymatoidea) of piscivorous birds. Can J Zool 1988a; 66(4): 885-895. http://dx.doi.org/10.1139/z88-131.

Measures LN. Epizootiology, pathology, and description of Eustrongylides tubifex (Nematoda: Dioctophymatoidea) in fish. Can J Zool 1988b; 66(10): 2212-2222. http://dx.doi.org/10.1139/z88-329.

Meneguetti DUO, Laray MPO, Camargo LMA. Primeiro relato de larvas de Eustrongylides sp. (Nematoda: Dioctophymatidae) em Hoplias malabaricus (Characiformes: Erythrinidae) no Estado de Rondônia, Amazônia Ocidental, Brasil. Rev Pan-Amaz Saúde 2013; 4(3): 55-58. http://dx.doi.org/10.5123/S2176-62232013000300008.

Mitchell AJ, Overstreet RM, Goodwin AE. Eustrongylides ignotus infecting commercial bass, Morone chrysops female X Morone saxatilis male, and other fish in the southeastern USA.J Fish Dis 2009; 32(9): 795-799. http://dx.doi.org/10.1111/j.1365-2761.2009.01051.x. PMid:19490394.

Montenegro AKA, Vieira ACB, Cardoso MML, Souza JERT, Crispim MC. Piscivory by Hoplias aff. malabaricus (Bloch, 1794): a question of prey availability? Acta Limnol Bras 2013; 25(1): 68-78. http://dx.doi.org/10.1590/S2179-975X2013000100008.

Moravec F. Nematodes of freshwater fishes of the Neotropical region. Prague: Academy of Sciences of the Czech Republic; 1998.

Narr LL, O'Donnell JG, Libster B, Alessi P, Abraham D. Eustrongylidiasis: a parasitic infection acquired by eating live minnows. J Am Osteopath Assoc 1996; 96(7): 400-402. http://dx.doi.org/10.7556/jaoa.1996.96.7.400. PMid:8758872.

Oyakawa OT. Family Erythrinidae. In: Reis R, Kullander S, Ferraris C, editors. Check list of the freshwater fishes of South and Central America. Porto Alegre: EDIPUCRS; 2003. p. 238-240.

Rego AA, Eiras JC. Ecologia da parasitose de peixes e aves do rio Cuiabá (Mato Grosso, Brasil) por Eustrongylides ignotus (Nematoda: dioctophymidae). Actas Col Luso-Esp Ecol Bacias Hidrogr Rec Zool 1988; 1: 335-341.

Rego AA, Vicente JJ. Eustrongylides ignotus Jagerskiold, 1909 (Nematoda: Dioctophymatoidea), parasito de peixes, anfíbios, répteis e aves. Distribuição e taxonomia. Cienc Cult 1988; 40(5): 478-483.

Rodrigues LC, Santos ACG, Ferreira EM, Teófilo TS, Pereira DM, Costa FN. Parasitologic aspects of traíra (Hoplias malabaricus) from the São Bento city, MA. Arq Bras Med Vet Zootec 2017; 69(1): 264-268. http://dx.doi.org/10.1590/1678-4162-8798.

Rodrigues MV, Pantoja JCF, Guimarães CDO, Benigno RNM, Palha MDDC, Biondi GF. Prevalence for nematodes of hygiene-sanitary importance in fish from Colares Island and Vigia, Pará, Brasil. $R$ Bras Ci Vet 2015; 22(2): 124-128. http://dx.doi.org/10.4322/rbcv.2015.364.

Santos AB, Melo JFB, Lopes PRS, Malgarim MB. Composição química e rendimento do filé da traíra (Hoplias malabaricus). Rev FZVA 2001; 7/8(1): 140-150.

Tamura K, Stecher G, Peterson D, Filipski A, Kumar S. MEGA6: Molecular Evolutionary Genetics Analysis Version 6.0. Mol Biol Evol 2013; 30(12): 2725-2729. http://dx.doi.org/10.1093/molbev/mst197. PMid:24132122.

Tavares LER, Campião KM, Costa-Pereira R, Paiva F. Helmintos endoparasitos de vertebrados silvestres em Mato Grosso do Sul, Brasil. Iheringia Zool 2017; 107(Suppl.): e2017106. http://dx.doi.org/10.1590/1678-4766e2017106.

Wittner M, Turner JW, Jacquette G, Ash LR, Salgo MP, Tanowitz HB. Eustrongylidiasis - a parasitic infection acquired by eating sushi. N Eng/J Med 1989; 320(17): 1124-1126. http://dx.doi.org/10.1056/NEJM198904273201706. PMid:2710174.

Xiong F, Li WX, Wu SG, Zou H, Wang GT. Molecular phylogeny and host specificity of the larval Eustrongylides (Nematoda: Dioctophmidae) from freshwater fish in China. J Parasitol 2013; 99(1): 137-144. http://dx.doi.org/10.1645/GE-3163.1. PMid:22924908.

Xiong F, Wang GT, Wu SG, Nie P. Development of Eustrongylides ignotus (Nematoda: Dioctophmida) in domestic ducks (Anas platyrhynchos domestica (L.)). J Parasitol 2009; 95(5): 1035-1039. http://dx.doi.org/10.1645/GE-2057.1. PMid:19463029. 